\title{
Assessment of Protein C Levels in Patients with Ischaemic Stroke in South-South Nigeria: A Study of Cases in University of Benin Teaching Hospital, Benin City
}

\author{
Oluomachi Charity Nnachi ${ }^{1}$, Robert Azu Nnachi ${ }^{2}$, Chukwuemeka Okorie Eze ${ }^{3}$, Ogah Emeka Onwe ${ }^{4}$, Augustine \\ Ejike Okoye ${ }^{1}$, Omolade Augustina Awodu ${ }^{5}$, Matilda Adesuwa Ojo $^{6} \&$ Ugochukwu Uzodinma Nnadozie $^{7}$ \\ ${ }^{1}$ Department of Haematology and Blood Transfusion, Alex Ekwueme Federal University Teaching Hospital \\ Abakaliki, Ebonyi State, Nigeria \\ ${ }^{2}$ Department of Accountancy/Banking and Finance, Faculty of Management and Social Sciences, Alex Ekwueme \\ Federal University Ikwo, Ebonyi State, Nigeria \\ ${ }^{3}$ Department of Internal Medicine, Alex Ekwueme Federal University Teaching Hospital Abakaliki, Ebonyi State, \\ Nigeria \\ ${ }^{4}$ Department of Paediatrics, Alex Ekwueme Federal University Teaching Hospital Abakaliki, Ebonyi State, \\ Nigeria \\ ${ }^{5}$ Department of Haematology and Blood Transfusion, University of Benin Teaching Hospital, Benin City, Edo \\ State, Nigeria \\ ${ }^{6}$ Department of Haematology and Immunology, University of Medical Sciences, Ondo State, Nigeria \\ ${ }^{7}$ Division of Plastic Surgery, Department of Surgery, Alex Ekwueme Federal University Teaching Hospital \\ Abakaliki, Ebonyi State, Nigeria \\ Correspondence: Oluomachi Charity Nnachi, Department of Haematology and Blood Transfusion, Alex \\ Ekwueme Federal University Teaching Hospital Abakaliki, Ebonyi State, Nigeria. Tel: 234-803-544-2642. E-mail: \\ ranex2x@gmail.com
}

Received: October 24, 2019 Accepted: December 5, 2019 Online Published: December 12, 2019

doi:10.5539/gjhs.v11n14p106 URL: https://doi.org/10.5539/gjhs.v11n14p106

\begin{abstract}
Background/Objective: Protein C (PC) is a vitamin $\mathrm{K}$ - dependent coagulation inhibitor produced in the liver. Acting together with its cofactor, protein S (PS), activated PC inhibits activated factors V and VIII thus downregulating thrombin generation which may predispose to inappropriate clot formation. This study aimed to ascertain the role of protein $\mathrm{C}$ deficiency in the development of ischaemic stroke in order to establish its relevance in stroke management in our environment.
\end{abstract}

Materials and Methods: Sixty-five ischaemic stroke patients and controls matched for age and sex were recruited in the study, blood samples were taken for haematological indices, prothrombin and activated partial thromboplastin times (PT and APTT) and protein C. Functional and qualitative assessments of protein C were done by chromogenic and immunoassay methods respectively. Data were analyzed with SPSS version 18 .

Results: A total of 130 subjects comprising 65 stroke subjects and 65 controls were recruited in the study. Mean age of the stroke group was $60.4 \pm 12.3 \mathrm{yrs}$ and the control is $59.0 \pm 14.1 \mathrm{yrs}$. The mean difference in PC Ag level, $\mathrm{PC} \operatorname{Ag}(\%)$ and functional activity between the groups were not statistically significant $(\mathrm{p}<0.05)$. Total WBC count in the stroke subjects was significantly higher than the controls $(\mathrm{p}=0.001)$. The platelet count was also higher and haemoglobin concentrations lower in stroke patients though not statistically significant. The prothrombin and activated partial thromboplastin times (APTT) in test and control groups are not significant.

Conclusion: This study showed that protein $\mathrm{C}$ may not play a significant role in the development of ischaemic stroke in our population.

Keywords: Protein C, Ischaemic stroke, adults, Benin City

\section{Introduction}

Stroke has been defined as a syndrome of rapidly developing clinical symptoms and signs of focal (or global) loss 
of cerebral functions, with symptoms lasting 24 hours or longer or resulting in death with no apparent cause other than of vascular origin (Longo et al., 2012) Stroke is a major cause of death and disability worldwide. Stroke prevalence in Nigeria is estimated at 58 per 100,000 with a 30-day case fatality rate as high as $40 \%$ (Osuntokun et al., 1979). Primary risk factors for stroke including hypertension, obesity, diabetes, diabetes mellitus, smoking and others have been evaluated extensively in our environment (Ogunrin et al., 2005). There is a scarcity of study on protein $\mathrm{C}$ levels in stroke patients. Protein $\mathrm{C}$ deficiency is a cause of hypercoagulable state. Hypercoagulable states including protein $\mathrm{C}$ deficiency predispose to thrombotic occlusion of a vessel and perfusion failure which can increase the risk for stroke. Ogunrin et al. (2005) in a study in Benin on Re-appraisal of risk factors for stroke in Nigerian Africans noted that the role of PC deficiency and other hypercoagulable states in stroke is unclear especially in developing countries like Nigeria since they are not routinely screened for.

Thrombosis is central to the major pathophysiological mechanism of ischaemic stroke. Protein $\mathrm{C}$ and normal vascular endothelial cells and other natural anticoagulants are important barriers to thrombosis. Defects or deficiencies of protein $\mathrm{C}$ may allow thrombogenesis even when a minimal trigger is present (Levine, 2005). Ischaemic stroke in protein $\mathrm{C}$ deficiency is mainly via cerebral sinus or cortical vein thrombosis, though arterial thrombosis can also be responsible. Activated protein C (APC) is a serine protease with important anticoagulant function. With the aid of its nonenzymatic cofactor, protein S, it inactivates activated factors V (FVa) and VIII (FVIIIa). It inactivates factor Va through a series of proteolytic cleavages and consequently inhibits the further generation of activated thrombin. The inactivation of FVa by APC requires two cleavages at Arg-306 and Arg-506 sites, located on the A1 and A2 domains of FVa, respectively (Nicolaes \& Dahlback, 2002; Kalafatis, Rand, \& Mann,1994). The cleavage of the Arg-306 site is accelerated 20-fold by protein S, a vitamin K-dependent cofactor for APC in plasma (Rosing, Hoekema, Nicolaes, Thomassen, Hencker, \& Varadi, 1995). Activated protein C also cleaves FVIIIa. This cleavage occurs at the homologous Arg-336 and Arg-562 sites, located on the A1 and A2 subunits respectively (Fay \& Smudzin, 1992). In contrast to FVa, cleavage of either site in the FVIIIa leads to a near-complete inactivation of the cofactor (i.eFVIIIa (Bertina, Wijngaarden, \& Cupers, 1984).

A natural common variant of FVa in which the protease recognition site at residue Arg-506 is mutated to Gln, is resistant to efficient inactivation by APC. This mutation is called FValeiden (Bertina, Koeleman, Koster, \& Reitsma, 1994). The association of FVa and FVIIIa with their target proteases, factor Xa and factor IXa in the prothrombinase and tenase complexes, respectively, prevents the APC recognition and inactivation of the cofactors (i.eFVa and FVIIIa) (O'Brien, Mastri, \& Fay, 2000; Gale, Yegneswaran, Xn, Pellequer, \& Griffin, 2007).

Activated protein $\mathrm{C}$ also has a profibrinolytic effect which is exerted via the thrombin-activatable fibrinolysis inhibitor (TAFI). Thrombin-activatable fibrinolysis inhibitor is activated by the IIa-TM complex and causes prolongation of clot lysis. The APC cleavage of factor Va inhibits the generation of IIa as well as IIa-TM mediated TAFI activation (Baizar, Nesheim, \& Tracy, 1996).

CYTOPROTECTIVE EFFECTS: Activated protein C bound to EPCR plays an important cytoprotective function which requires EPCR and protease-activated receptor 1 (PAR-1). These include regulating gene expression, anti-inflammatory effects, anti-apoptotic effects and protecting endothelial barrier function. The anti-inflammatory roles include inhibition of the proinflammatory properties of FIIa via inhibition of FIIa generation. Activated protein $\mathrm{C}$, by its anticoagulant function, can inhibit the function of tissue factor (TF) and indirectly inhibit inflammation. It has been shown to decrease inflammatory mediator-induced TF expression in endothelial protein C receptor (EPCR) - dependent manner (Shua, Kobayashia, Fukudomeb, Tsuneyoshib, Kimotob, \& Teraoa, 2000) and down-regulates vascular adhesion molecules. It has anti-inflammatory effects on endothelial cells and leukocytes. Lack of these functions can indirectly be linked to arterial thrombosis in PC deficiency.

Variations in PC activity have been observed in stroke patients, but a causal relationship is yet to be fully established. The role of Thrombophilia states including protein $\mathrm{C}$ deficiency is underestimated in stroke in our environment. Hence this study is focus to evaluate PC activity in patients with ischaemic stroke in Benin City Nigeria.

\section{Materials and Methods}

This was a case-control study carried out between March and June, 2014 at the University of Benin Teaching Hospital (UBTH), Benin City, Edo State, Nigeria. This institution is a major referral facility for the surrounding south-south states of Delta, Rivers, Edo, Bayelsa, Akwa Ibom and Cross River including Kogi, and Ondo States amongst others. One hundred and thirty subjects comprising 65 ischaemic stroke patients (Case group) and 65 age and sex-matched healthy individuals without a history of ischaemic stroke as controls. 
Inclusion criteria included adults (18 years and above) and CT scan evidence of ischaemic stroke for the case group. For the controls, negative history of cerebrovascular accident, patients on anticoagulant therapy, those with liver disease and renal disease were excluded.

Participants' personal data, medical history and stroke risk factors including hypertension, diabetes smoking, alcohol intake, and drug history were obtained by means of an interviewer-administered questionnaire complemented by documentations in patients' case notes. Stroke severity was assessed based on disability in personal care and mobility in stroke patients using the Barthel's index (Mahoney \& Barthel, 1965). Scores of the items in the index were obtained using direct observation, self-report, or responses from family/friends. Total scores were calculated by summing up the individual item scores. Scores are weighted and range from 0 (dependence) to 100 (independence). Scores of 0-20 indicate total dependence; 21-60: severe dependence: 61-90: moderate dependence and 91-99: slight dependence.

Eleven millilitres (11 mls) of venous blood were drawn from the antecubital vein of study subjects via the aseptic procedure. Of the blood collected, $4.5 \mathrm{ml}$ of whole blood was dispensed into a plain sample bottle containing $0.5 \mathrm{ml}$ of $0.109 \mathrm{M}$ sodium citrate $(3.2 \%)$ for antithrombin estimation. Three and a half millilitres of blood was dispensed into commercially prepared $\mathrm{K}_{2}$ ethylene di-amine tetra-acetic acid (EDTA) bottle for blood count analysis. The remaining $3 \mathrm{ml}$ dispensed into commercial heparin bottle was used for liver function test (LFT). The citrated sample centrifugation at $2500 \mathrm{~g}$ for 15 minutes and plasma extracted and stored at $-20^{\circ} \mathrm{C}$. It was subsequently thawed in a water bath, at $37^{\circ} \mathrm{C}$ prior to protein $\mathrm{C}$ assay.PC activity was measured using TECHNOCHROM protein $\mathrm{C}$ reagent kit (The Protac method) by Technoclone GmbH, Brunner str. 67, 1230 Vienna, Austria. LOT: OK12B01. REF: 5341013, while protein C antigen was estimated using enzyme immunoassay test kit TECHNOZYM protein C ELISA by Technoclone GmbH, Brunner str. 67, 1230 Vienna, Austria. LOT: 12021122. REF: TC12021.

Blood count was evaluated on the same day of collection using an automated blood cell counter (Erma Inc. Haematology Analyzer. PCE-210).

All participants gave an informed written/or verbal consent. The study was approved by the University of Benin Teaching Hospital Ethics and Review Committee.

Data obtained were analyzed using statistical programming for social sciences (SPSS) package version 18. A weighting was given to the different degrees of stroke severity using a Likert scale. Continuous variables were expressed as mean and standard deviation while categorical variables were expressed in frequencies. The differences in the mean of continuous variables between the groups were tested using students' t-test while chi-square or Fisher's exact test were used as appropriate to test associations. Pearson correlation coefficient was used to correlate protein $\mathrm{C}$ levels with stroke severity index and haematological parameters. P-value $\leq 0.05$ was considered significant.

\section{Results}

The mean age of case subjects was $60.4 \pm 12.3 \mathrm{yrs}$ while those of the controls were $59.9 \pm 14.1 \mathrm{yrs}$. The stroke subjects included $42(64.6 \%)$ males and 23(50.8\%) females as against $45(69.2 \%)$ males and 20(30.8\%) females in the controls. Details of the demographic parameters are presented in Table 1.

The identified risk factors for stroke in the case subjects were hypertension, diabetes mellitus, smoking, positive history of previous stroke, positive family history of stroke in 46 (70.8\%), $14(21.5 \%), 3(3.6 \%), 13(20.0 \%)$ and 6 $(9.2 \%)$ respectively. Twenty-nine (44.6\%) and $10(15.4 \%)$ of the control have hypertension and diabetes mellitus respectively. 
Table 1. Demographic parameters and identifiable risk factors in study participants

\begin{tabular}{|c|c|c|}
\hline Variables & $\begin{array}{l}\text { Ischaemic Stroke } \\
(\mathrm{n}=65)\end{array}$ & $\begin{array}{l}\text { Controls p value } \\
(n=65)\end{array}$ \\
\hline Age $($ Mean \pm SD $)$ & $60.4 \pm 12.3$ & $59.9 \pm 14.1$ \\
\hline \multicolumn{3}{|l|}{ Sex } \\
\hline Males & $42(64.6)$ & $45(69.2)$ \\
\hline Females & $23(35.4)$ & $20(30.8)$ \\
\hline \multicolumn{3}{|l|}{ Ethnicity } \\
\hline Bini & $33(50.8)$ & $40(61.5)$ \\
\hline Esan & $8(12.3)$ & $11(16.9)$ \\
\hline Etsako & $4(6.2)$ & $0(0.0)$ \\
\hline Ibo & $4(6.2)$ & $8(12.3)$ \\
\hline Ika & $5(7.7)$ & $3(4.6)$ \\
\hline Urhobo & $3(4.6)$ & $2(3.1)$ \\
\hline Yoruba & $3(4.6)$ & $1(1.5)$ \\
\hline \multicolumn{3}{|l|}{ Identifiable Risks } \\
\hline Hypertension & $46(70.8)$ & 29 (44.6) \\
\hline Diabetes Mellitus & $14(21.5)$ & $2(3.1)$ \\
\hline Smoking & $3(3.6)$ & $2(3.1)$ \\
\hline Alcohol intake & $17(26.2)$ & $10(15.4)$ \\
\hline Positive family history of Stroke & $6(9.2)$ & $0(0.0)$ \\
\hline Previous Stroke & $13(20)$ & $0(0.0)$ \\
\hline Previous VTE & $1(1.5)$ & $0(0.0)$ \\
\hline
\end{tabular}

The stroke subjects had a significantly higher total white cell count $(\mathrm{P}=0.001)$. Also, their platelets count was higher and haemoglobin concentrations lower than that of controls but these are not statistically significant. The mean cell volume of the stroke patients $(78.32 \pm 8.72 \mathrm{fl})$ was significantly higher than those of control subjects $(75.00 \pm 8.34 \mathrm{fl}) \mathrm{p}=0.028$. The prothrombin and activated partial thromboplastin times (APTT) in test and control groups are not significant. Details are presented in Table 2.

Table 2. Haematological parameters of study participants

\begin{tabular}{llll}
\hline Variables & $\begin{array}{l}\text { Ischaemic Stroke } \\
(\mathbf{n = 6 5})\end{array}$ & $\begin{array}{l}\text { Controls } \\
(\mathbf{n = 6 5})\end{array}$ & P Value \\
\hline $\mathrm{WBC}\left(\mathrm{x} 10^{3} / \mu \mathrm{l}\right)$ & $7.23 \pm 3.01$ & $5.27 \pm 1.55$ & $0.001^{*}$ \\
$\mathrm{HB}(\mathrm{g} / \mathrm{dl})$ & $11.97 \pm 2.17$ & $12.61 \pm 2.12$ & 0.090 \\
$\mathrm{MCH}(\mathrm{pg})$ & $24.42 \pm 3.70$ & $23.72 \pm 4.07$ & 0.303 \\
$\mathrm{MCV}(\mathrm{fl})$ & $78.32 \pm 8.72$ & $75.00 \pm 8.34$ & $0.028^{*}$ \\
$\mathrm{MCHC}$ & $30.63 \pm 2.84$ & $31.28 \pm 3.77$ & 0.268 \\
Platelet $\left(\mathrm{x} 10^{3} / \mu \mathrm{l}\right)$ & $197.92 \pm 64.81$ & $186.35 \pm 54.49$ & 0.269 \\
PT $(\mathrm{secs})$ & $13.68 \pm 2.47$ & $13.34 \pm 1.60$ & 0.356 \\
APTT(secs) & $37.11 \pm 3.14$ & $37.86 \pm 1.43$ & 0.081
\end{tabular}

Hb: Haemoglobin; WBC: White Blood Cell Count; MCH: Mean Corpuscular Haemoglobin; MCHC: Mean Corpuscular Haemoglobin Concentration; MCV: Mean Cell Volume; PT: Prothrombin Time; APTT: Activated partial Thromboplastin Time. 
The mean PC Ag level, PC $\mathrm{Ag}(\%)$ and functional activity of the stroke and control groups were not statistically significant $2.27 \pm 1.74 \mathrm{vs} 2.45 \pm 1.51 \mathrm{p}=0.546$ and $86.31 \pm 55.50 \mathrm{vs}, 81.42 \pm 18.66 \mathrm{p}=0.502$ and $86.31 \pm$ $22.66 \mathrm{vs} 89.18 \pm 22.6, \mathrm{p}=0.454$ respectively.

Table 3. Protein C levels in study participants

\begin{tabular}{llll}
\hline Variables & Ischaemic Stroke $(\mathbf{n}=\mathbf{6 5})$ & Controls $(\mathbf{n}=\mathbf{6 5})$ & P Value \\
\hline PC activity $(\%)$ & $86.31 \pm 22.66$ & $89.18 \pm 22.66$ & 0.454 \\
PC Ag Level $(\mu \mathrm{g} / \mathrm{ml})$ & $2.27 \pm 1.74$ & $2.45 \pm 1.51$ & 0.546 \\
PC Ag $(\%)$ & $86.31 \pm 55.50$ & $81.42 \pm 18.66$ & 0.502 \\
\hline
\end{tabular}

PC: Protein C; PC Ag: Protein C Antigen.

Twenty-one of the study participants have PC antigen deficiency. Eleven (16.9\%) of these are ischaemic stroke subjects while ten (15.4\%) are controls. PC antigen deficiency was not significantly associated with ischaemic stroke (p-value $=0.812$ ). Also, seven participants have functional PC deficiency, four $(6.2 \%)$ are stroke subjects while $3(4.6 \%)$ are controls. Similarly, there was no significant association between ischaemic stroke and functional PC activity deficiency ( $\mathrm{p}$-value $=1.000$ ). Details are shown in Table 3.

Out of the twenty-one participants with PC antigen deficiency, seventeen had isolated PC antigen deficiency while four (3 stroke subjects and 1 control subject) had concurrent PC antigen and functional deficiency (type 1 deficiency). Three (1 stroke subject and 2 controls) of the seven participants with functional PC deficiency does not have PC antigen deficiency (type II PC deficiency)

Table 4. Correlation between Severity of Stroke (Bartel Index) and PC in Subjects with Ischaemic Stroke

\begin{tabular}{lllll}
\hline & & PC activity & PCAg Level & PC $(\%)$ \\
\hline \multirow{2}{*}{ Bartel Index } & $\mathrm{R}$ & 0.051 & 0.194 & -0.002 \\
& P value & 0.689 & 0.121 & 0.985 \\
\hline
\end{tabular}

$\mathrm{R}=$ pearson's correlation coefficient.

There was no significant association between the identifiable risk factors for stroke and PC deficiency as seen in Table 4.

Table 4. Demographic variables and risk factors for stroke in ischemic stroke patients with and without PC deficiency

\begin{tabular}{llll}
\hline Variables & $\begin{array}{l}\text { Ischaemic Stroke with } \begin{array}{l}\text { PC Activity } \\
\text { Pge }(\text { Mean } \pm \mathrm{Sd})\end{array} \\
\text { normal PC Act. }\end{array}$ & $\begin{array}{l}\text { Stroke } \\
\text { with }\end{array}$ & P Value \\
\hline Sex & $63.5 \pm 9.3$ & $60.2 \pm 12.5$ & 0.609 \\
Males & $3(4.6)$ & $22(33.8)$ & 1.000 \\
Females & $1(1.5)$ & $39(60.0)$ & 0.313 \\
\hline Identifiable Risk & & & 0.569 \\
Hypertension & $4(6.2)$ & $41(64.6)$ & 1.000 \\
Diabetes Mellitus & $0(0.0)$ & $14(21.5)$ & 0.278 \\
Smoking & $0(0.0)$ & $3(4.6)$ & 0.264 \\
Alcohol Intake & $2(3.1)$ & $15(23.1)$ & 1.000 \\
Positive family history of stroke & $1(1.5)$ & $5(7.7)$ & 1.000 \\
Previous Stroke & $1(1.5)$ & $12(18.5)$ & $1(1.5)$ \\
Previous VTE & $0(0.0)$ & & \\
\hline
\end{tabular}

No significant correlation exists. 


\section{Discussion}

Protein $\mathrm{C}$ deficiency has been reported to be an apparent risk factor for ischaemic stroke in some studies(MartinezMartinez,Cazorla-Garcia, Rodriquez de Antonio,\& Martinez, 2010; Sakata, Kario, \& Sakata, Kato,Kario, Matsuyama, Miyat., \& Katayama, 1999; Uysal, Anlar, \& Altay, 1989) however some other researchers disagree with this finding (Adams \& Kapelle, 1995; Horellou, Conard, Bertina, \& Samania, 1984; Coller, Owen, Jesty, Horowitz, Reitmann, Spear, \& Yeh, 1987). At present, the contribution of PC deficiency to the development of venous thrombosis (Goldenberg \& Manco-Johnson, 2008; Levine, 2005) is well established but its role in the pathogenesis of arterial thrombosis including ischaemic stroke is still uncertain. This index study observed that there was no significant difference in the mean PC activity and antigen levels between the stroke subjects and their control counterparts. This finding is similar to what was reported by D'Angelo et al. (1988) in their study which showed that mean PC concentration in plasma was not different in their stroke patients and controls.

The findings in this study are however in contrast to those of Anzola, Magoni, and Ascan (1993)who reported significant low values of PC in patients with acute stroke $(<24 \mathrm{hrs})$. The low PC in acute stroke is fairly common and reflects massive activation of coagulation due to enhanced liberation of thromboplastin from damaged brain tissue with consequent rapid removal of PC from circulation once activated by thrombin-thrombomodulin complex (Folsom, Ohira, Yamagishi, \& Cushman, 2009; Kennedy, Warner, \& Kaim, 1995). Kennedy et al. (1995) reported lower PC levels in children with an acute ischaemic stroke which however returned to normal after some months. The findings of the later was contradicted by that of Haapaniemi, TatliskuMak, Soinne, and Kaste (2002) who demonstrated a high plasma level of PC during the acute stroke event but subsequently normalized. Due to late presentation to the hospital, most of the stroke subjects in the index study were recruited later than $24 \mathrm{hrs}$ after the event and reports have shown that there is restoration of the levels of coagulation proteins including PC to normal levels after the acute event $(<24 \mathrm{hrs})$ of stroke when the levels may be reduced following the acute phase response and coagulation activation due to enhanced liberation of thromboplastin from damaged brain tissue (D'Angelo et al., 1988; Gissel, Undas., Agnieszka, Brummel-ziedens \& Man, 2010).

In some other studies (Sakata et al., 1999; Simioni, Zanardis, \& Saracino, 1992) lower PC levels were reported in ischaemic stroke subjects of younger age group (young adults <55yrs). These studies supporting an association between PC deficiency and ischaemic stroke in young adults could be due to the fact that the yield for diagnosing an inherited hypercoagulable state including AT deficiency is greatest among young stroke patients when compared to older adults where the conventional risk factors for stroke such as hypertension, diabetes mellitus and dyslipidaemia are more prevalent. The mean age of the stroke subjects in the index study was $60.4 \pm 12.3 \mathrm{yrs}$ and they had multiple risk factors such as hypertension, diabetes mellitus, smoking, positive family history among other risk factors for stroke. These factors including their age must have contributed significantly to the pathogenesis of stroke.

The finding that PC antigen deficiency was seen in both study groups agree with Haywood, Liesner, Pindora, and Ganesan (2005), and Miletich, Sherman, and Broze (1987) who reported that PC deficiency is common in the general population but paradoxically thrombosis is uncommon. This further suggests that PC deficiency is a relatively mild risk factor for thrombosis. Barinagaremateria, Caritu- Brito, Izaguirre, and Lapena, (1994) also reported no significant difference in the prevalence of PC deficiency between cases and controls.

Four of the study participants had type 1 PC deficiency (50\% reduction in PC antigen and functional levels) while three had type II deficiency (50\% reduction in PC functional activity). This suggests that type I PC deficiency is more common in the study population. This is similar to reports of Paul, Roberto, Rey Gabriela De Larranga, Lepra, Alovonso, and Saposnik (2001) and Kay, Loh, and Sharma (2011) who reported that type I deficiency state is more common.

There was also no statistically significant correlation between PC and ischemic stroke. This is in keeping with reports of PC deficiency in ischaemic stroke from some other studies (Folsom et al., 2009; Miletich, 1987; Kay et al., 2011) which found no association between PC and ischaemic stroke. This further buttresses the fact that PC deficiency may not have a significant role in the pathogenesis of ischaemic stroke and other forms of arterial thrombosis (De Stefano, Chiusolo, Martinelli, Mannucci, \& Paciaroni, 1994).

The correlation between PC levels and the severity of stroke using the Bartel index (Mahoney \& Barthel, 1965) was not significant. This is not unexpected as the stroke subjects had similar PC levels with the controls and it implies that there is no direct involvement of PC deficiency in the development of cerebral infarcts as reported in some studies (Adams, 1995; Horellou, 1984; Rosenberg \& Aird, 1999). Haapenienmi et al. (2002) in his study similarly found that PC levels did not correlate with stroke severity and neither does it predict recurrence of ischaemic stroke. However, Anzola et al. (1993) reported that ischaemic stroke patients with PC deficiency had 
more severe morbidity and mortality but also alluded to the fact that the low PC in acute stroke may reflect massive coagulation activation and consumption during the acute event of a stroke.

The role of simple coagulation tests (PT and APTT) in screening for hypercoagulable states like an ischaemic stroke was assessed but this study found no statistically significant correlation between the APTT, PT, platelet count and PC level in the ischaemic stroke subjects. Busari, Shokunbi, and Jeremiah (2006) in their study of plasma level of coagulation parameters in sickle cell patients (a hypercoagulable state) noted prolonged APTT in these patients. This finding was contradicted by Abudullah (2012) and Mckenna, Bachmann, and MiroQuesafa (1977) who reported shortened APTT with associated elevated FVIII and a hypercoagulable state during acute thrombotic episodes. They later authors, however, noted that acute phase response during acute thrombotic episodes could distort the levels of the coagulation factors unpredictably. Due to late presentation, most of the stroke subjects in this study were recruited in the chronic stage (later than 24 hours of stroke event) when acute phase responses and coagulation activation has subsided. This may account for the normalization of the APTT and PT.

A Similar study by Emre, Crgun, Unal, and Coskuno (2007) regarding the levels of haematocrit and platelet count, did not reveal any statistically significant difference between the case and control group. However, there were significantly higher WBC values in the stroke subjects $(\mathrm{P}=0.001)$. This could be due to the inflammatory response with the rapid accumulation of granulocytes and later mononuclear leucocytes following brain ischaemia.

There was no significant association between functional PC deficiency and the identifiable risk factors for stroke in stroke subjects. Functional PC and PC antigen levels are not reduced in ischaemic stroke patients. The more common type of PC deficiency in the study population is type 1. Protein $\mathrm{C}$ deficiency is not significantly associated with ischaemic stroke in our environment, therefore, it may not be justifiable to routinely assess PC in ischaemic stroke subjects in our environment; however, in younger subjects where there are no identifiable risk factors, PC may be assayed.

We recommend a cohort study of subjects with PC deficiency to evaluate their risk of ischaemic stroke.

\section{Competing Interests Statement}

The authors declare that there are no competing or potential conflicts of interest.

\section{References}

Abudullah, W. Z. (2012). Shortened APTT: A simple but important marker of Hypercoagulable State during Acute Coronary Event, Coronary Artery Disease- New insight and novel approaching (Dr. Angelo Squari, 978 958- 51 - 0344).

Adams, H. P., \& Kapelle, L. J. (1995). Ischemic Stroke in Young Adults. Experience in 329 Patients enrolled in the Iowa Registry of Stroke in Young Adults. Archives of Neurology, 52(5), 491-495. https://doi.org/10.1001/archneur.1995.00540290081021

Anzola, G. P., Magoni, M., \& Ascan, E. (1993). Early Prognostic Factors in Ischaemic Stroke; the role of Protein C and Protein S. Stroke, 24, 1496-1500. https://doi.org/10.1161/01.STR.24.10.1496

Baizar, L., Nesheim, M. E., \& Tracy, P. B. (1996). The Profibrinolytic effect of activated Protein C in Clots formed $\begin{array}{lllll}\text { from Plasma } & \text { is } & \text { TFAI-Dependent. } & \text { Blood, }\end{array}$ https://doi.org/10.1182/blood.V88.6.2093.bloodjournal8862093

Barinagaremateria, F., Caritu- Brito, C., Izaguirre, R., \& Lapena, A. (1994). Prothrombotic States in Young People with Idiopathic Stroke.A prospective study. Stroke, 25(1), 287-290. https://doi.org/10.1161/01.STR.25.2.287

Bertina, R. M., Koeleman, B. P. C., Koster, T., \& Reitsma, P. H. (1994). Mutation in Blood Coagulation Factor V associated with resistance to activated Protein C. Nature, 369, 64-67.https://doi.org/10.1038/369064a0

Bertina, R, M., Wijngaarden, A. V., \& Cupers, R. (1984). Factor IXa protects Factor VIIa against inactivation by

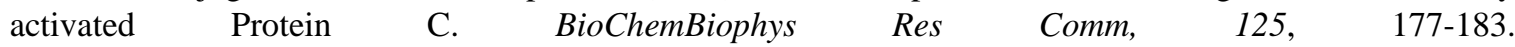
https://doi.org/10.1016/S0006-291X(84)80351-4

Busari, F. I., Shokunbi, W. A., \& Jeremiah, Z. A. (2006). Plasma level of some Coagulation Parameters in Nigerian Homozygous Sickle Cell Patients. Haematology, 11, 375-399. https://doi.org/10.1080/10245330600841287

Coller, B. S., Owen, J., Jesty, J., Horowitz, D., Reitmann, M. J., Spear, J., \& Yeh, T. (1987). Deficiency of protein $\mathrm{S}$, protein $\mathrm{C}$ and antithrombin and arterial thrombosis. Arteriosclerosis, 7, 456-461. https://doi.org/10.1161/01.ATV.7.5.456 
D'Angelo, A., Landi, G., Viagano D Angelo.s, Orazio, E. N., Boccardi, E., Candelise, L., \& Mannucci, P. M. (1988). Protein C in Acute stroke. Stroke, 19(5), 579-583. https://doi.org/10.1161/01.STR.19.5.579

De Stefano, V., Chiusolo, P., Martinelli, I., Mannucci, K., \& Paciaroni, K. (1994). Abnormalities of Hemostasis in Ischemic Stroke. N Engl J. Med., 330, 885-891.

Emre, U., Ergun, U., Unal, A., Coskun, O., Atasoy, H. T., Yildiz, H., ... \& Inan, E. L. (2007). The Role of Acute Phase Reactants in Acute Ischemic Stroke. Journal of Neurological Sciences, 24, 1064-069.

Fay, P. J., \& Smudzin, T. M. (1992). Characterization of the interaction between the A2 Subunit and A1/A3-C1-C2 Dimer in Human Factor Vina. Journal of BiolChem, 267, 13246-13250.

Folsom, A. R., Ohira, T., Yamagishi, K., \& Cushman, M. (2009). Low Protein C and Incidence of IschaemicStroke and Coronary Heart Disease: The Atherosclerosis in Communities (ARIC) Studies. Journal of Thromb Haemost, 7(11), 1774. https://doi.org/10.1111/j.1538-7836.2009.03577.x

Gale, A. J., Yegneswaran, S., Xn, X., Pellequer, J. L., \& Griffin, J. H. (2007). Characterization of a Factor Xa binding site on Factor Va near the Arg-506 activated Protein C Cleavage Site. Journal of BiolChem, 282, 21848-21855. https://doi.org/10.1074/jbc.M702192200

Gissel, M., Undas, A., Agnieszka, S., Brummel-ziedens, K. E., \& Mann, K. G. (2010). Plasma Factor and Inhibitor Composition Contributes to Thrombin Dynamics in Patients with acute or previous Cerebrovascular Accident. Thrombosis Research, 126(4), 262-269. https://doi.org/10.1016/j.thromres.2010.07.002

Goldenberg, N. A., \& Manco-Johnson, M. J. (2008). Protein C deficiency.Haemophilia, 14, $1214-1221$. https://doi.org/10.1111/j.1365-2516.2008.01838.x

Haapaniemi, E., TatliskuMak, T., Soinne, L., \& Kaste, M. (2002). Natural Anticoagulants (Antithrombin, Protein $\mathrm{C}$ and Protein S) In Patients with mild to moderate Ischaemic Stroke. Actaneurolscand, 105(2), 107-14. https://doi.org/10.1034/j.1600-0404.2002.10112.x

Haywood, S., Liesner, R., Pindora, S., \& Ganesan, V. (2005). Thrombophilia and first Arterial Ischemic Stroke: A Systemic Review. Arch Dis child, 90, 402-405. https://doi.org/10.1136/adc.2004.049163

Horellou, M. H., Conard, J., Bertina, R. M., \& Samania, M. (1984). Congenital protein C Deficiency and Thrombotic Disease in nine French Families. $\mathrm{Br}$ med Journal, 289, 1285-1287. https://doi.org/10.1136/bmj.289.6454.1285

Kalafatis, M., Rand, M. D., \& Mann, K. G. (1994). The Mechanism of Inactivation of Human Factor V and Human Factor Va by Activated Protein C. Journal of BiolChem, 269, 31869-31880.

Kay, W. P., Loh, P. K., \& Sharma, V. K. (2011). Role of Investigating Thrombophilic Disorders in Young Stroke. Stroke Research and Treatment. http://dx.doi .org/10.4061/2011/670138

Kennedy, C. R., Warner, G., \& Kaim. (1995). Protein C Deficiency and Stroke in early life. Dev Med Child Neurol, 37, 723-730. https://doi.org/10.1111/j.1469-8749.1995.tb15018.x

Levine, S. R. (2005). HypercoagulableStates and Stroke, A selective review. CNS spear, 10(7), 567-78. https://doi.org/10.1017/S109285290001021X

Longo, D. L., Fauci, A. S., \& Kasper, D. L. (2012). Harrison's Principles of International Medicine (18th ed). USA: The McGraw - Hill.

Mahoney, F. I., \& Barthel, D. W. (1965). Functional Evaluation: The Barthel Index. Md State Med Journal, 14, 61-65. https://doi.org/10.1037/t02366-000

Martinez-Martinez, M., Cazorla-Garcia, R., Rodriquez de Antonio, L., \& Martinez, S. (2010). Hypercoagulability and Ischemic Stroke in Young Patients. Neurologia, 25(6), 343-8. https://doi.org/10.1016/S2173-5808(10)70065-1

Mckenna, R., Bachmann, F., \& MiroQuesafa, M. (1977). Thrombo-Embolism in Patients with abnormally short APTT. Thrombosis Haemostasis, 38(4), 893-899. https://doi.org/10.1055/s-0038-1651907

Miletich, J., Sherman, L., \& Broze, J. (1987). Absence of Thrombosisin subject with Heterozygous Protein C Deficiency. $N$ J med, 317, 991-998. https://doi.org/10.1056/NEJM198710153171604

Nicolaes, G. A., \& Dahlback, B. (2002). Factor V and Thrombotic Diseases: Description of a Janus-Faced Protein. Arterioscler Thromb Vase Biol, 22, 530-538.https://doi.org/10.1161/01.ATV.0000012665.51263.B7

'Brien, L. M., Mastri, M., \& Fay, P. J. (2000). Regulation of Factor Villa by Human Activated Protein C and Protein 
S: Inactivation of Cofactor in the intrinsic Factor Xase. Blood, 95, 1714-1720.https://doi.org/10.1182/blood.V95.5.1714.005k40_1714_1720

Ogunrin, O., Amu, E., \& Danesi, M. (2003).Re appraisal of Risk Factors for Stroke in Nigerian Africans.African Journal of Neurological Sciences (AJNS), 24(2).

Osuntokun, B. O., Badamosi, O., Akinkugbe, O. O., Oyediran, A. B., \& Carlisle, R. (1979). Incidence of Stroke in an African city: Results from the Stroke Registry at Ibadan, Nigeria, 1973-1975. Stroke, 10, $205-207$. https://doi.org/10.1161/01.STR.10.2.205

Paul, C. R., Roberto, E. P., Rey Gabriela De Larranga, Lepra, S., Alovonso, B., \& Saposnik, G. (2001). Activated Protein C Resistance in Patients with Arterial Ischemic Stroke. Journal of Stroke and Cerebrovascular Diseases, 10, 128-131. https://doi.org/10.1053/jscd.2001.25464

Rosing, J., Hoekema, L., Nicolaes, G. A., Thomassen, M. C., Hencker, H. C., \& Varadi, K. (1995). Effects of Protein S and Factor Xa on Peptide Bond Cleavages during inactivation of Factor Va and Factor Va506Q by activated Protein C. J. BiolChem, 270, 27852-27858. https://doi.org/10.1074/jbc.270.46.27852

Rosenberg, R. D., \& Aird, W. C. (1999). Vascular Bed Specific Haemostasis and Hypercoagulable States. N Eng J Med, 340, 1555-1564. https://doi.org/10.1056/NEJM199905203402007

Sakata, T., Kato, H., Kario, K., Matsuyama, T., Miyata, T., \& Katayama, Y. (1999). Analysis of 45 episodes of Arterial Occlusive Disease in Japanese Patients with Congenital Protein C Deficiency. Thrombosis Research, 69-78. https://doi.org/10.1016/S0049-3848(98)00194-7

Shua, F., Kobayashia, H., Fukudomeb, K., Tsuneyoshib, N., Kimotob, M., \& Teraoa, T. (2000). Activated Protein C suppresses Tissue Factor Expression on U937 Cells in the Endothelial Protein C Receptor - Dependent Manner. FEES Lett, 477, 208-212. https://doi.org/10.1016/S0014-5793(00)01740-3

Simioni, P., Zanardis, \& Saracino, A. (1992). Occurrence of Arterial Thrombosis in a cohort of Patient with Hereditary Deficiency of Clotting Incubators. Journal of Medicine, 23(1), 61-74. https://doi.org/10.1016/0049-3848(92)90254-8

Uysal, S., Anlar, B., \& Altay, C. (1989). Risk of Protein C in Childhood Cerebro Vascular Occlusive Accidents. European Journal of Paediatrics, 3, 216-218. https://doi.org/10.1007/BF01958286

\section{Copyrights}

Copyright for this article is retained by the author(s), with first publication rights granted to the journal.

This is an open-access article distributed under the terms and conditions of the Creative Commons Attribution license (http://creativecommons.org/licenses/by/4.0/). 